\title{
STRATEGI PENGEMBANGAN USAHA GARAM REBUS DI KABUPATEN BREBES
}

\author{
Indah Setiawati ${ }^{1}$ \\ ${ }^{1}$ Program Studi Agribisnis, Fakultas Pertanian, Universitas Jenderal Soedirman \\ iindahs@unsoed.ac.id
}

\begin{tabular}{|c|c|}
\hline $\begin{array}{l}\text { Article History } \\
\text { Received }[26|07| 2020] \\
\text { Revised }[06|08| 2020] \\
\text { Accepted }[15|08| 2020]\end{array}$ & $\begin{array}{l}\text { ABSTRACT } \\
\text { As a maritime country, Indonesia potentials in producing salt based on } \\
\text { community. The high import of salt indicates that the potential it has has not } \\
\text { been developed to the maximum. Boiled salt produced by the coastal } \\
\text { communities of Brebes Regency has the potential to be developed. The purpose } \\
\text { of this study was to determine the strategy of boiling salt business development } \\
\text { in Brebes Regency by knowing the internal and external factors of the } \\
\text { business. The results showed that the internal factors of salt business included } \\
\text { supporting and inhibiting factors. Low education is a limiting factor and } \\
\text { hereditary skills in boiled salt production are business supporting factors from } \\
\text { the internal side. The external inhibiting factor of the boiled salt business is } \\
\text { that there are cheaper competing products resulting in less competitive prices } \\
\text { as table salt products. Supporting factors from the external side is the } \\
\text { availability of abundant raw materials so that production can be increased } \\
\text { more optimally. Seeing the existence of supporting and inhibiting factors from } \\
\text { both internal and external sides, the strategy of boiling salt business } \\
\text { development in Brebes Regency is directed to improve marketing skills by } \\
\text { creating quality products that have market segmentation in certain circles so } \\
\text { as to be able to produce competitive products. }\end{array}$ \\
\hline $\begin{array}{l}\text { Keywords: } \\
\text { Strategi, } \\
\text { Pengembangan } \\
\text { Usaha, Garam } \\
\text { Rebus. }\end{array}$ & $\begin{array}{l}\text { ABSTRAK } \\
\text { Indonesia sebagai negara maritim merupakan potensi yang besar dalam } \\
\text { menghasilkan garam yang berbasis pada kelompok usaha rakyat. Tingginya } \\
\text { impor garam mengindikasikan potensi yang dimiliki belum dikembangkan } \\
\text { secara maksimal. Garam rebus yang dihasilkan oleh masyarakat pesisir } \\
\text { Kabupaten Brebes memiliki potensi untuk dikembangkan. Tujuan penelitian } \\
\text { adalah untuk mengetahui strategi pengembangan usaha garam rebus di } \\
\text { Kabupaten Brebes dengan mengetahui faktor internal dan eksternal usaha. } \\
\text { Hasil penelitian menunjukkan bahwa faktor internal usaha garam meliputi } \\
\text { faktor pendukung dan penghambat. Adanya pendidikan yang rendah } \\
\text { merupakan faktor penghambat dan keterampilan yang sudah turun temurun } \\
\text { dalam produksi garam rebus merupakan faktor pendukung usaha dari sisi } \\
\text { internal. Faktor penghambat eksternal usaha garam rebus adalah adanya produk } \\
\text { pesaing yang lebih murah sehingga harga yang kurang kompetitif sebagai } \\
\text { produk garam meja. Faktor pendukung dari sisi eksternal adalah tersedianya } \\
\text { bahan baku melimpah sehingga produksi dapat ditingkatkan secara lebih } \\
\text { maksimal. Melihat adanya faktor pendukung dan penghambat baik dari sisi } \\
\text { internal maupun eksternal, maka strategi pengembangan usaha garam rebus di } \\
\text { Kabupaten Brebes adalah diarahkan untuk meningkatkan keterampilan } \\
\text { pemasaran dengan menciptakan mutu produk yang memiliki segmentasi pasar } \\
\text { pada kalangan tertentu sehingga mampu menghasilkan produk yang bersaing. }\end{array}$ \\
\hline
\end{tabular}

\section{PENDAHULUAN}

Indonesia sebagai negara maritim memiliki potensi yang besar dalam menghasilkan garam. Sayangnya potensi ini belum dikembangkan dengan maksimal sehingga impor garam masih tinggi. Pengembangan usaha garam yang sangat potensial di Indonesia adalah dalam bentuk usaha rakyat sesuai kondisi sosial ekonomi masyarakat pesisir setempat. Pemerintah perlu mendorong pembangunan lumbung garam nasional berbasis sentra garam rakyat (Biro Komunikasi Kementerian Maritim, 2020). 
Garam merupakan produk yang dibutuhkan baik sebagai konsumsi rumah tangga maupun industri serta farmasi. Kebutuhan garam setiap tahun selalu meningkat seiring dengan bertambahnya jumlah penduduk dan pertumbuhan industri. Pada 2019 kebutuhan garam nasional diperkirakan naik 5,98\% menjadi 4,2 juta ton. Kebutuhan konsumsi garam dalam negeri ini banyak dipenuhi dari impor garam daripada produksi dalam negeri. Menurut Kementerian Koordinator Bidang Perekonomian, produksi garam sebesar 2,3 juta ton sedangkan impornya lebih tinggi yakni mencapai 2,7 juta ton (Jayani, 2019).

Kabupaten Brebes adalah salah satu wilayah penghasil garam krosok dengan luas lahan garam produktif $545 \mathrm{Ha}$ dan total produksi pada tahun 2018 sebesar 46.733,34 ton (Dinas Perikanan Kabupaten Brebes, 2018). Di samping penghasil garam krosok, Kabupaten Brebes juga mempunyai sentra pengolah garam rebus konsumsi yang terletak di Desa Limbangan Kecamatan Losari dan Dukuh Pandansari Desa Kaliwlingi Kecamatan Brebes. Produksi untuk setiap pengolah garam rebus rata-rata $40-50 \mathrm{~kg}$ per hari dengan harga jual Rp.6000/kg.

Garam rebus menjadi mata pencaharian masyarakat setempat secara turun temurun sejak jaman penjajahan Belanda. Masyarakat yang memiliki keterbatasan lahan memilih memproduksi garamnya dengan cara direbus selama berjam-jam hingga menghasilkan kristal garam yang halus. Kelompok usaha garam di Kabupaten Brebes merupakan kelompok usaha rakyat sehingga memiliki keterbatasan mulai dari modal dan tenaga kerja. Meski garam rebus merupakan produk yang sudah turun temurun, namun dalam usahanya mengalami banyak kendala seperti keterbatasan ruang produksi, sumber daya manusia yang masih rendah, dan sebagainya. Dengan demikian perlu dilakukan peningkatan nilainilai sosial ekonomi antara lain tecermin dari kegiatan investasi serta tingkat produktivitas, pendapatan dan kesejahteraan masyarakat.(Sangadji,S.S, 2018)

Menurut Lestina (2018), faktor-faktor yang mempengaruhi usaha garam meliputi modal, luas lahan dan tenaga kerja serta lama kerja. Oleh karena itu, perlu dilakukan kajian mengenai strategi yang tepat dalam pengembangan usaha garam rebus di Kabupaten Brebes.

Tujuan penelitian adalah untuk mengetahui faktor internal dan eksternal yang mendukung dan menghambat usaha garam rebus di Kabupaten Brebes serta mengetahui strategi yang tepat dalam pengembangan usaha tersebut.

\section{KAJIAN PUSTAKA}

Garam sudah menjadi komoditas politik sejak masa pemerintahan Belanda. Garam selain menjadi komoditas strategis tetapi juga komoditas politik terbukti pada masa pemerintahan Raffles tahun 1813. Raffles menyelenggarakan monopoli garam di seluruh daerah kekuasaannya dari sisi produksi maupun distribusinya (Munadi, 2016). Garam berdasarkan penggunaannya digolongkan menjadi garam konsumsi dan garam industri. Kegunaan garam sebagai konsumsi memiliki kriteria kemurnian $\mathrm{NaCl}$ yang lebih rendah dari garam untuk industri bahkan farmasi yang menyaratkan kandungan $\mathrm{NaCl}$ hampir 100\% (Pakaya, dkk. 2015).

Usahatani garam dilakukan melalui kegiatan pemanfaatan air laut sebagai bahan baku untuk diproduksi menjadi garam, baik garam konsumsi maupun garam industri. Usahatani garam umumnya dilakukan oleh masyarakat pedesaan yang berada di pesisir laut (Aunurrofiqi, 2018). Karakteristik tersebut memberikan dampak pada banyaknya kendala dalam pengembangan usaha garam rakyat. Menurut Mustofa dan Turjono (2015), teknologi yang dimiliki masyarakat petani garam masih sangat rendah sehingga sangat tergantung pada alam. Dalam produksinya, petani menguapkan air laut didalam petak pegaraman dengan tenaga sinar matahari tanpa sentuhan 
teknologi apapun, sehingga walaupun bahan baku melimpah namun salinitas dan polutan yang terlarut sangat beragam.

Kondisi lain yang juga dihadapi petani garam rakyat diantaranya kepemilikan lahan yang masih sempit (di bawah 0,5 hektar), mutu garam yang rendah $(\mathrm{NaCl}$ lebih kecil dari $95 \%)$, tata letak pegaraman rakyat umumnya tidak teratur dan terpencar-pencar, sarana jalan yang menghubungkan petak/lahan dengan jalan raya sebagai sarana transportasi hampir dikatakan tidak ada atau tidak memadai. Menurut hasil penelitian Lestina (2016), usaha garam rakyat dipengaruhi beberapa faktor yakni modal, luas lahan dan tenaga kerja dan memiliki pengaruh yang positif dan signifikan terhadap produksi garam sedangkan variabel tenaga kerja dan lama kerja tidak signifikan terhadap produksi garam.

\section{METODE PENELITIAN}

Penelitian ini menggunakan bentuk penelitian kualitatif yang dilakukan pada suatu obyek dan mengkondisikannya seperti apa adanya. Menurut Sutopo (2002:111) "Penelitian kualitatif studi kasusnya mengarah pada pendeskripsian secara rinci dan mendalam mengenai potret kondisi tentang apa yang sebenarnya terjadi di lapangan studinya". Secara teori penelitian kualitatif mempunyai pengertian sebagai suatu pernyataan sistematis yang berkaitan dengan seperangkat preposisi yang berasal dari data dan diuji kembali secara empiris. Waktu penelitian dilakukan selama 4 bulan yakni dari Bulan Januari - April 2020.

\section{Subjek Penelitian}

Subjek dalam penelitian ini adalah masyarakat di kawasan pesisir Penambangan, tepatnya di Desa Limbangan Kecamatan Losari dan Dukuh Pandansari Desa Kaliwlingi Kecamatan Brebes yang meliputi tokoh-tokoh masyarakat, masyarakat sebagai petani garam, masyarakat petani garam sebagai pengusaha serta masyarakat umum.

\section{Teknik Pengumpulan Data}

Pengumpulan data dilakukan dengan cara mengumpulkan berbagai informasi atau data-data seputar pemanfaatan sumber daya alam pesisir yang dilakukan oleh para petani garam di kawasan pesisir Kecamatan Brebes. Sangadji S, dkk (2019) menyebutkan bahwa teknik pengumpulan data penelitian terdiri dari obsevasi dan pengumpulan data dengan kuesioner, namun teknik pengumpulan data dilakukan dalam penelitian ini yaitu:

1. Teknik observasi (pengamatan):

Teknik ini dilakukan untuk mendapatkan data mengenai potensi sumberdaya pesisir dan kehidupan sosial ekonomi masyarakat petani garam setempat.

2. Teknik interview (wawancara):

Untuk mendapatkan data primer maka menggunakan teknik wawancara semi terstruktur (semi structured interview) yakni wawancara yang pelaksanaannya lebih bebas dan menggunakan pertanyaan-pertanyaan terbuka yang dilakukan secara purposive dengan nara sumber atau responden yang dianggap paling banyak mengetahui permasalahan yang dihadapi masyarakat pesisir dalam pengelolaan kawasan konservasi laut yaitu petani garam, petani garam pedagang, tokoh masyarakat, pejabat Dinas Perikanan dan Kelautan serta instansi terkait.

3. Kuesioner :

Untuk mendapatkan data primer digunakan kuesioner sebagai alat untuk mengukur. Respondennya adalah petani garam, tokoh masyarakat, dan pejabat Dinas Perikanan dan Kelautan serta instansi terkait. 


\section{Analisis Data}

1. Analisis Lingkungan Internal dan Eksternal Kawasan Pesisir Kecamatan Brebes

2. Strategi Pengembangan Usaha Garam Rebus di Kawasan Pesisir Kecamatan Brebes Kabupaten Brebes.

Salah satu strategi yang dapat digunakan dalam penelitian adalah analisis SWOT. Menurut Rangkuti (2005:18) analisis SWOT adalah identifikasi berbagai faktor secara sistematis untuk merumuskan strategi pengembangan unit pengolahan Garam. Analisis ini didasarkan pada logika yang dapat memaksimalkan kekuatan (Strengths) dan peluang (Opportunities), namun secara bersamaan dapat meminimalkan kelemahan (Weaknesses) dan ancaman (Threats). Berdasarkan analisis ini dapat diketahui keterkaitan antara faktor internal dengan faktor eksternal, sehingga dapat menghasilkan kemungkinan alternatif strategis. S. Sangadji, S., \& Suhardi, S. (2019)

\section{HASIL DAN PEMBAHASAN \\ Faktor Eksternal Usaha Mikro}

Faktor pendukung dan penghambat dilihat dari dua aspek yakni internal dan eksternal. Identifikasi terhadap faktor-faktor eksternal usaha garam rebus di Kabupaten Brebes menghasilkan sejumlah peluang dan ancaman yang disebut sebagai faktor strategis eksternal usaha.

Tabel 1. Hasil Identifikasi Peluang dan Ancaman

\begin{tabular}{lc}
\hline PELUANG (O) & ANCAMAN (T) \\
\hline 1. Tren minat produk sehat & Pesaing garam krosok \\
2. terjual di daerah sekitar & \\
tempat produksi \\
3. Pelatihan usaha \\
4. Program pendampingan \\
5. Ketersediaan bahan baku \\
6. Tersedianya kredit dengan \\
$\quad$ bunga ringan \\
\hline
\end{tabular}

Sumber: data diolah, 2019

Berdasarkan hasil wawancara diketahui bahwa faktor yang menjadi peluang dalam kegiatan usaha garam rebus diantaranya adanya tren masyarakat terhadap produk yang sehat dan produk dapat terjual di daerah sekitar tempat produksi. Tren masyarakat terhadap produk yang lebih sehat merupakan peluang terbesar bagi usaha garam rebus, mengingat garam rebus memiliki ciri khas garam yang lebih sehat karena dibuat tanpa pemurnian yang menurunkan kualitas garam. Menurut Sudiarta, dkk. (2014), terdapat faktor eksternal utama usaha yakni peluang akan tingginya minat masyarakat terhadap produk. Produk selama ini terjual di daerah sekitar sebagai garam krosok yang lebih baik dari garam krosok yang dibuat melalui proses penjemuran di lahan. Masyarakat sekita membeli garam krosok dari garam rebus untuk bahan baku industri makanan seperti ikan pindang maupun telur asin. Hal ini menggambarkan bahwa masyarakat di daerah sekitar terhadap produk yang ditawarkan memiliki minat yang tinggi. Selain itu faktor lain yang menjadi peluang usaha adalah adanya pelatihan dan pendampingan usaha dari dinas terkait. Pelatihan dan pendampingan usaha merupakan faktor eksternal yang menjadi peluang usaha karena dapat meningkatkan keterampilan dan keuntungan. Selama ini, Dinas Kelautan dan Perikanan 
Kabupaten Brebes sangat konsen terhadap pengembangan usaha garam rebus karena dinilai memiliki keunikan yang sudah turun temurun. Pelatihan dan pendampingan dari dinas terkait akan sangat bermanfaat dalam pengembangan manajerial usaha, pengembangan inovasi produk, hingga pemasaran. Menurut Ahmad dan Rahayu (2018), model kemitraan dengan program pendampingan yang intensif kepada mitra usaha dapat meningkatkan relasi dan kepercayaan dalam berwirausaha. Pendampingan dalam membangun relasi dan kepercayaan menjadi hal utama dalam menguatkan peluang yang menjadi faktor eksternal usaha mikro.

Hal yang menjadi ancaman dalam usaha garam rebus adalah adanya pesaing garam krosok yang harganya lebih murah. Harga garam krosok pesaing yang diproduksi dengan teknik penjemuran di lahan terbuka mencapai Rp1.000,- sedangkan garam rebus jika dijual curah bisa mencapai Rp6.000,-. Menurut Sudiarta (2014), ancaman usaha skala mikro memiliki ancaman terbesar berupa adanya persaingan usaha dengan produk sejenis yang lebih murah. Keterbatasan modal mengakibatkan harga produksi yang lebih tinggi. Persoalan yang dihadapi usaha garam rebus sedikit unik karena produk curah yang dihasilkan memang berbeda dengan garam curah garam krosok lain di pasar. Kelompok usaha garam rebus harus mampu menangkap peluang pasar berupa segmentasi pasar yang lebih tinggi, yakni fokus menjual produk garam rebus dengan mutu yang lebih sehat pada konsumen tertentu.

\section{Faktor Internal Usaha Mikro}

Berdasarkan identifikasi terhadap faktor-faktor internal usaha didapatkan sejumlah kekuatan dan kelemahan yang disebut sebagai faktor strategis internal usaha kemudian dilakukan penilaian dengan cara wawancara kepada pemilik usaha.

Tabel 2. Identifikasi Faktor Internal

\begin{tabular}{ll}
\hline KEKUATAN $(\mathbf{S})$ & KELEMAHAN $(\mathbf{W})$ \\
\hline 1. Status kepemilikan tempat tinggal & 1. Pendidikan rendah \\
2. Status kepemilikan tempat usaha & 2. Promosi offline \\
3. Usia produktif & 3. pemasaran offline \\
4. Keterampilan yang dimiliki & 4. intensitas promosi individu \\
5. Pengalaman Usaha &
\end{tabular}
Sumber: data diolah, 2019

Dari hasil analisis diketahui bahwa faktor internal yang menjadi kekuatan ada lima diantaranya status keterampilan yang dimiliki. Keterampilan yang dimiliki berkaitan dengan kemampuan manajerial mulai dari kegiatan produksi hingga pemasaran. Kegiatan pelatihan berkaitan dengan keterampilan usaha, sehingga merupakan hal yang sangat penting dilakukan secara berkala dan berkelanjutan mengikuti perkembangan pasar dan teknologi. Aspek sumberdaya manusia berkaitan dengan aspek teknik operasi dan menjadi faktor pendukung usaha mikro (Purwidianti dan Rahayu, 2015). Menurut Sehabudin, dkk (2016), faktor sosial seperti tingkat pendidikan dan pengalaman usaha merupakan faktor penumbuh usaha dan bisnis usaha mikro dan kecil.

Faktor internal lain yang menjadi pendukung kegiatan usaha garam rebus adalah status kepemilikan tempat usaha, status kepemilikan tempat tinggal, pengalaman usaha dan usia pemilik usaha (usia produktif). Usia produktif 30 s.d. 45 tahun menjadi faktor kekuatan internal dalam merintis usaha mikro (Putra dan Basri, 2019). Kepemilikan tempat usaha dan tempat tinggal menjadi faktor utama selanjutnya karena berhubungan dengan alokasi 
modal. Jika kepemilikan tempat usaha dan tempat tinggal adalah sewa maka membutuhkan alokasi modal untuk sewa dan mungkin akan mengurangi alokasi untuk biaya produksi maupun investasi sehingga kegiatan usaha terhambat. Menurut Sudiarta, dkk (2014) faktor strategis internal yang menjadi kekuatan terbesar adalah pemasaran yakni lokasi usaha yang strategis sedangkan kelemahan utama adalah aspek teknis operasi yakni kualitas produk yang masih berubah-ubah atau fluktuatif yang disebabkan keterampilan karyawan yang berbeda-beda. Menurut Putra dan Basri (2019), faktor-faktor yang melatarbelakangi pengusaha UMKM membuka usaha yaitu karena alasan modal yang dibutuhkan tidak terlalu besar, tingkat pendidikan dan keahlian yaitu pendidikan yang dibutuhkan hanya cukup di tingkat SLTP dengan keahlian yang dimiliki tidak terlalu tinggi. Serta faktor jarak tempat tinggal ke tempat usaha yang tidak terlalu jauh.

\section{Strategi Pengembangan Usaha Garam}

Analisis matriks SWOT dilakukan dengan membandingkan secara sistematis hasil kekuatan dan kelemahan dari lingkungan internal dengan peluang dan ancaman dari lingkungan eksternal secara terukur untuk menghasilkan strategi pengembangan bisnis yang sesuai sebagaimana terlihat dalam tabel berikut ini. Erdil dan Erdiyik (2015) mengungkapkan bahwa meningkatkan nilai guna produk, meningkatkan kesadaran merek, strategi positioning, dan kemitraan merupakan strategi utama dalam mengembangkan usaha mikro. Oleh karena itu, strategi di bidang pemasaran sangat dibutuhkan bagi pengembangan usaha garam di Kabupaten Brebes.

Tabel 3. Matriks SWOT

\begin{tabular}{|c|c|c|}
\hline & KEKUATAN (S) & KELEMAHAN (W) \\
\hline & $\begin{array}{l}\text { 1) Status kepemilikan } \\
\text { tempat tinggal } \\
\text { 2) Status tempat usaha } \\
\text { milik sendiri } \\
\text { 3) Usia produktif } \\
\text { 4) Keterampilan yang } \\
\text { dimiliki } \\
\text { 5) Memiliki pengalaman } \\
\text { usaha yang cukup }\end{array}$ & $\begin{array}{l}\text { 1) Pendidikan rendah } \\
\text { 2) Promosi dilakukan } \\
\text { secara offline } \\
\text { 3) pemasaran } \\
\text { dilakukan secara } \\
\text { offline } \\
\text { 4) intensitas promosi } \\
\text { individu yang } \\
\text { rendah }\end{array}$ \\
\hline $\begin{array}{l}\text { PELUANG (O) } \\
\text { 1) Tren minat produk } \\
\text { sehat } \\
\text { 2) Pasar potensial } \\
\text { berada di daerah } \\
\text { sekitar } \\
\text { 3) Pelatihan usaha } \\
\text { 4) Program } \\
\text { pendampingan dari } \\
\text { pemerintah } \\
\text { 5) Ketersediaan bahan }\end{array}$ & $\begin{array}{l}\text { STRATEGI S-O } \\
\text { Aktif mengikuti program } \\
\text { pelatihan baik dari dinas } \\
\text { maupun mandiri untuk } \\
\text { meningkatkan keterampilan } \\
\text { dan penjualan. }\end{array}$ & $\begin{array}{l}\text { STRATEGI W-O } \\
\text { Mengikuti pelatihan } \\
\text { pemasaran online untuk } \\
\text { meningkatkan kemampuan } \\
\text { penjualan secara online dan } \\
\text { strategi promosinya. }\end{array}$ \\
\hline
\end{tabular}




\begin{tabular}{|c|l|l|}
\hline \multicolumn{1}{|c|}{ baku } & & \\
\hline ANCAMAN (T) & STRATEGI S-T & STRATEGI W-T \\
1) Pesaing garam & Gunakan kekuatan untuk & Meningkatkan \\
& menghindari ancaman & keterampilan pemasaran \\
& Mengalokasikan modal & agar terjual tepat pada \\
& usaha pada perluasan pasar & segmentasi pasar tertentu \\
& di luar daerah dengan & dan dapat terjual hingga di \\
& segmentasi pasar yang & luar daerah/luar kota. \\
& lebih khusus & \\
\hline
\end{tabular}

Sumber: data diolah, 2019

\section{SIMPULAN DAN SARAN \\ Simpulan}

Berdasarkan hasil penelitian dapat disimpulkan bahwa kegiatan usaha garam rebus di Kabupaten Brebes merupakan sektor penting untuk dikembangkan karena memiliki daya dukung internal yang mencakup usia produktif, status kepemilikan usaha, keterampilan dan pengalaman usaha serta daya dukung eksternal yang mencakup ketersediaan bahan baku, tren minat garam sehat, dan pelatihan dan pendampingan dari dinas terkait.

Beberapa faktor penghambat yang menjadi kelemahan internal dan perlu ditingkatkan diantaranya pendidikan yang rendah, promosi dilakukan secara offline, pemasaran dilakukan secara offline, dan intensitas promosi individu yang rendah/jarang dilakukan. Sedangkan faktor penghambat eksternal yang perlu diperhatikan adalah adanya pesaing garam krosok yang lebih murah.

Berdasarkan analisis SWOT, beberapa strategi kebijakan yang perlu dilakukan pada usaha garam rebus di Kabupaten Brebes adalah dengan menyediakan paket pendidikan dan keterampilan para pelaku usaha baik di pendidikan formal maupun non formal seperti pelatihan pemasaran online sehingga jangkauan pemasaran dapat lebih luas dan dapat mengatasi ancaman pesaing yang ada di luar kota.

\section{Saran}

Perlu dilakukan kajian mengenai model pengembangan usaha berbasis pemasaran digital/online marketing dengan mengelola produk yang tersegmentasi pada pasar khusus. Diperlukan kegiatan sosialisasi tentang kredit usaha, supaya usaha mikro dapat lebih mudah memahami dan mengakses.

\section{DAFTAR PUSTAKA}

Ahmad, F. dan Rahayu, E. 2018. Model Kemitraan dalam Pemberdayaan Usaha Mikro Pedesaan. Jurnal Ilmu Kesejahteraan Sosial, Jilid 19, Nomor 2.

Aunurrofiqi. I. 2018. Hubungan Karakteristik Kewirausahaan Petani Garam dengan Keberhasilan Usaha Garam di Kabupaten Rembang. Skripsi. Departemen Agribisnis, Fakultas Ekonomi dan Manajemen, Institut Pertanian Bogor, Bogor.

Biro Komunikasi Kementerian Maritim. 2020. Pemerintah Dorong Pembangunan Lumbung Garam Nasional Berbasis Sentra Garam Rakyat. https://maritim.go.id/pemerintah-dorong-pembangunan-lumbung-garam-nasionalberbasis-sentra/ Daiakses 2 Juli 2020.

Dinas Perikanan Kabupaten Brebes. 2018. Laporan Produksi Garam di Kabupaten Brebes. 
Erdil, A. dan H. Erbiyik, 2015. Selection Strategy via Analytic Hierarchy Process: An Application for a Small Enterprise in Milk Sector. Procedia - Social and Behavioral Sciences 195 ( 2015 ) 2618 - 2628.

Jayani, D. H. 2019. Impor Garam Lebih Tinggi daripada Produksi Garam Nasional. https://databoks.katadata.co.id/datapublish/2019/09/24/impor-garam-lebih-tinggidaripada-produksi-garam-nasional\# Diakses pada tanggal 1 Juli 2020.

Lestina. 2016. Faktor-faktor Yang Mempengaruhi Tingkat Produksi Garam di Kabupaten Jeneponto. Skripsi. Jurusan Ilmu Ekonomi Fakultas Ekonomi dan Bisnis Islam, Universitas Islam Negeri Alauddin, Makassar

Munadi, E. 2016. Dilema Pergaraman di Indonesia. Badan Pengkajian dan Pengembangan Perdagangan, Al Mawardi Prima, Jakarta.

Mustofa dan Turjono, E. 2015. Analisis Optimalisasi Terhadap Aktivitas Petani Garam Melalui Pendekatan Hulu Hilir Di Penambangan Probolinggo. Jurnal WIGA Vol. 5 No. 1

Pakaya, N. K., Sulistijowati, R., dan Dali, F. A. 2015. Analisis Mutu Garam Tradisional di Desa Siduwonge Kecamatan Randangan Kabupaten Pohuwato Provinsi Gorontalo. Nikè: Jurnal Ilmiah Perikanan dan Kelautan. Volume 3, Nomor 1.

Purwidianti, W. dan T.S.M. Rahayu. 2015. Pengaruh Faktor Internal dan Eksternal Terhadap Kinerja Usaha Industri Kecil dan Menengah di Purwokerto Utara. Kinerja, Volume 19, No.1, Th. 2015: Hal. 149-159-150

Putra, A. dan Basri, H. 2019. Representasi Kehidupan Sosial Ekonomi Pelaku Usaha Mikro Kecil Menengah (UMKM) Dikawasan Objek Wisata Percandian Muaro Jambi-Provinsi Jambi. Jurnal Bisnis, Manajemen dan Perbankan. Vol. 5, No. 1.

Rangkuti, F. 2005. Analisis SWOT Teknis Membedah Kasus Bisnis. Gramedia Pustaka Utama, Jakarta.

Sangadji, S. S. (2018). Peran Strategis Perguruan Tinggi dalam Perspektif Pembangunan Daerah Di Provinsi Maluku Utara. https://doi.org/10.31219/osf.io/xf9kg

Sangadji, S., Suhardi, S., \& Ali, C. P. M. (2019). Pengaruh Bauran Pemasaran terhadap Keputusan Pembelian Sagu Rasa pada Gabungan Kelompok Tani Tagafura di Kelurahan Jaya Kota Tidore Kepulauan. Optimal: Jurnal Ekonomi dan Kewirausahaan, 13(2), 142-157.

S. Sangadji, S., \& Suhardi, S. (2019). Strategi Pengembangan Usaha Budidaya Ikan Kerapu Di Kelurahan Djikocobo Kota Tidore Kepulauan. Aksara Public, 3(4), 179-187. Retrieved from http://aksarapublic.com/index.php/home/article/view/361

Sehabudin, U., Saleh, A., Warcito. 2016. Faktor-Faktor Penumbuh Usaha Mikro-Kecil di Wilayah Kota dan Kabupaten Bogor. Journal of Management and Business Review, Vol.13, No. 1.

Sutopo H.B. 2002. Metodologi Penelitian Kualitatif. Sebelas Maret University Press, Surakarta.

Sudiarta, I. Putu Lanang Eka, I. Ketut Kirya, and Wayan Cipta. Analisis Faktor-Faktor Yang Mempengaruhi Kinerja Usaha Mikro Kecil Dan Menengah (UMKM) Di Kabupaten Bangli. Jurnal Jurusan Manajemen 2(1). 